$10-1951$

\title{
Seasonal Patterns Of Oyster Setting In The James River And Chesapeake Bay
}

Jay D. Andrews

Virginia Fisheries Laboratory

Follow this and additional works at: https://scholarworks.wm.edu/vimsarticles

Part of the Aquaculture and Fisheries Commons, and the Marine Biology Commons

\section{Recommended Citation}

Andrews, Jay D., Seasonal Patterns Of Oyster Setting In The James River And Chesapeake Bay (1951).

Ecology, 32(4), 752-758.

$10.2307 / 1932744$

This Article is brought to you for free and open access by the Virginia Institute of Marine Science at W\&M ScholarWorks. It has been accepted for inclusion in VIMS Articles by an authorized administrator of W\&M ScholarWorks. For more information, please contact scholarworks@wm.edu. 
tion of the area occupied: (Nomenclature follows eighth ed. of Gray's manual by M. L. Fernald, 1950).

\section{Shrub Layer}

Ground hemlock (Taxus canadensis)

Witch hobble (Viburnum alnifolium)

Witch hazel (Hamamelis virginiana)

Beaked hazelnut (Corylus rostrata)

Blackberry (Rubus sp.)

\section{Tree Reproduction}

Beech Fagus grandifolia

Hemlock Tsuga canadensis

White Pine Pinus strobus

Yellow Birch Betula lutea

Northern Red Oak Quercus rubra var. borealis

White Ash Fraxinus americana

Black Cherry Prunus serotina

Red Maple Acer rubrum

Sugar Maple $A$. saccharum

Striped Maple $A$. pennsylvanicum

Hop Hornbeam Ostrya virginiana

\section{Ground Vegetation}

Typical coniferous forest species

Wintergreen Gaultheria procumbens

Arbutus Epigaea repens

Partridge berry Mitchella repens

Canada mayflower Maianthemum canadense

Wild sassaparilla Aralia nudicaulus

Indian cucumber root Medeola virginiana

Twisted stalk Streptopus amplexifolius

New England Aster Aster acuminatus

Red trillium Trillium erectum

Beech drops Epifagus virginiana

Indian pipe Monotropa uniflora

\section{Meadow species}

Royal fern Osmunda regalis

Cinnamon fern Osmunda cinnamomea

Lady fern Athyrium filix-femina

New York fern Dryopteris novaboracense

Goldenrod Solidago sp.

Loosestrife Lythrum sp.

Meadowrue Thalictrum dioicum

Poverty grass Danthonia sp.

Lutz (1930 b) reported the composition of the remnant of original white pine forest at Heart's Content, Pennsylvania, as beech, hemlock, maple, birch, white pine and chestnut, which agrees well with the composition reported here. $\mathrm{He}$ listed a much larger number of tree species, indicative of the more Alleghenian region. Probably, if the Bradford stand were of equal size many other species would be recorded. In another paper (Lutz 1930a) he listed all the coniferous forest ground vegetation recorded here and a host of other species. Among the shrub layer, however, Taxus canadensis and Corylus rostrata were not included. Lutz's conclusion that the high white pine representation in the hemlock beech association is a temporary condition is confirmed by the prevalence of hemlock seedlings and saplings in the Bradford stand, and the complete lack of white pine reproduction over $6^{\prime \prime}$ in height.

\section{Literature Cited}

Lutz, H. J. 1930a. The vegetation of Heart's Content, a virgin forest in northwestern Pennsylvania. Ecology 11: 1-30.

- 1930b. Original forest composition in northwestern Pennsylvania as indicated by early land survey notes. Jour. For. 28: 1098-1103.

Hillsboro, New Hampshire

Henry I. Baldwin

\section{SEASONAL PATTERNS OF OYSTER SETTING IN THE JAMES RIVER AND CHESAPEAKE BAY ${ }^{1}$}

The James River seedbeds are one of the few oyster-growing areas of the world still operated successfully as a free fishery on natural oyster grounds. It is characteristic of free fisheries that much is taken out and little is put back. For some 50 years, the James River seedbeds have continuously furnished most of the seedoysters (young oysters) for the planters of Virginia. That they are still productive is strong testimony to the natural fitness of the area for oyster culture. Yet, their survival as seed

1 Contributions from the Virginia Fisheries Laboratory, No. 34 . grounds must be attributed in no small measure to the laws prohibiting modern mechanized harvesting methods.

The James River seed area is comprised of public oystering grounds, the boundaries of which were established by the Baylor Survey of 1894. The area extends from near the James River Bridge at Brown Shoal to Deep Water Shoal Lighthouse (Fig. 1). Its importance as a source of seed-oysters for the entire oyster industry of Virginia, places it high on the list of fishery problems for biological study. Failure of the seedbeds would be catastrophic for the industry, planters and tongers alike; improvement, 


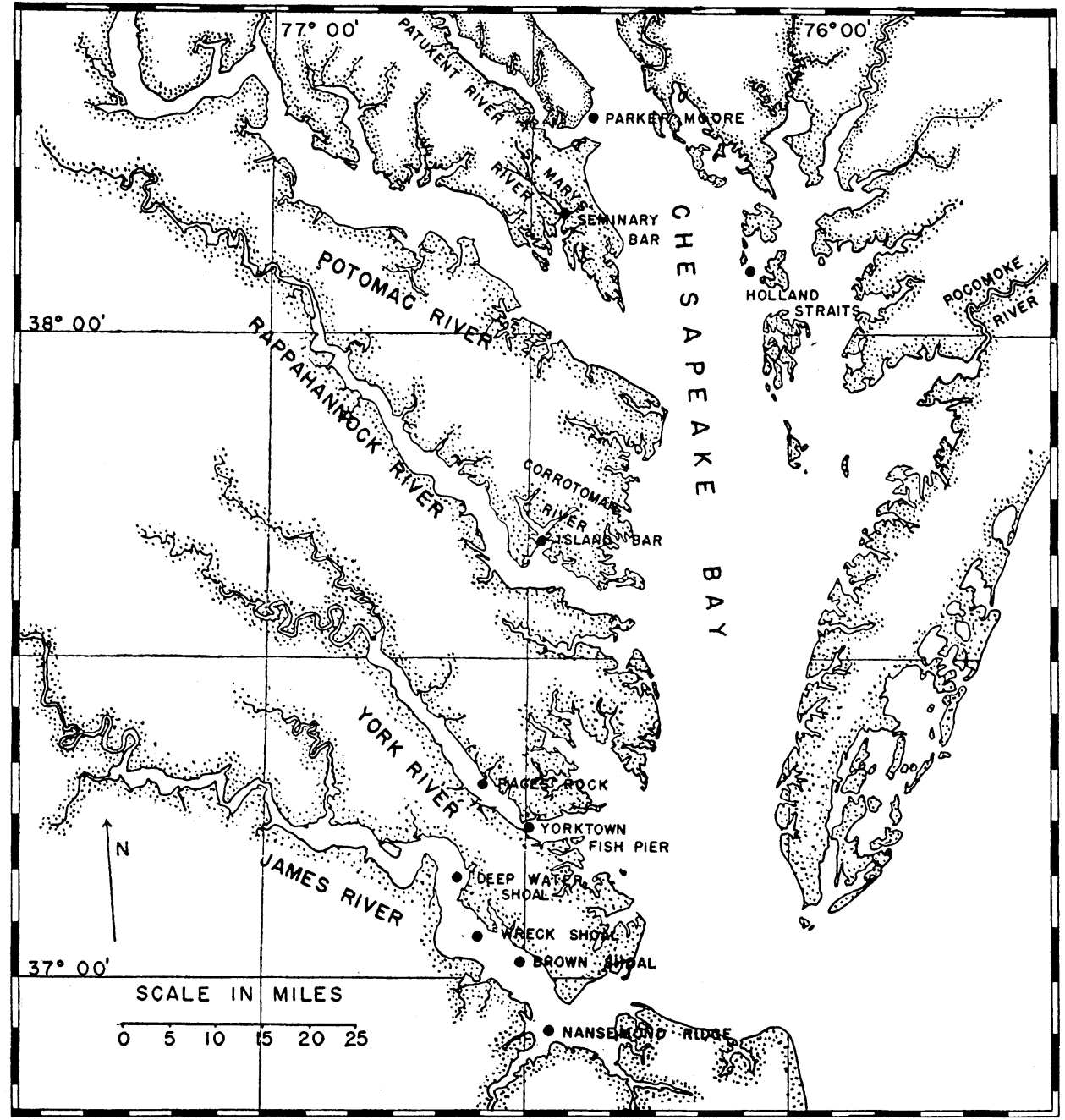

FIg. 1. Map of Lower Chesapeake Bay showing major tributaries and sampling stations.

which seems quite possible, would add to the nation's food supply and enhance the natural resources of the state.

The most important and basic biological feature of the James River seed area is the excellent strike (spatfall) which occurs each year without fail. Several years ago the Virginia Fisheries Laboratory began a study of oyster setting in the James River. The immediate problem was to determine whether planting shells in late summer would increase the setting and survival of spat, for it had been observed that sets occurred rather frequently during August and September. In this paper results are presented from only one type of data, the weekly setting records. The seasonal pattern of setting is com- pared with other areas and possible explanations are discussed.

\section{Methods Used in Testing Weekly Spatfall}

Test shells were placed in bags of one and one-half inch chicken wire. These bags were 18 inches long and 8 to 10 inches in diameter and so constructed that when filled all shells were less than four inches from the outside. Twenty shells were marked and distributed randomly in each quarter bushel bag for counting. The bags were then placed on the river bottom in pairs and left for one week. After exposure, the inner faces of the marked shells were examined for oyster spat. Successive series of bags were 
TABLE I. Variations in setting at Wreck Shoal, James River

\begin{tabular}{c|c|c|c}
\hline \hline Year & $\begin{array}{c}\text { Length of } \\
\text { setting } \\
\text { season } \\
\text { in days }\end{array}$ & \multicolumn{2}{|c}{$\begin{array}{c}\text { Average number of spat } \\
\text { per shell face }\end{array}$} \\
\cline { 3 - 4 } & & $\begin{array}{c}\text { Total of all } \\
\text { weekly sets }\end{array}$ & $\begin{array}{c}\text { Greatest } \\
\text { weekly set }\end{array}$ \\
\hline 1947 & 85 & 157 & 35.0 \\
1948 & 98 & 85 & 18.2 \\
1949 & 99 & 108 & 18.9 \\
1950 & 84 & 109 & 39.2 \\
\hline
\end{tabular}

2 The average number of spat which would have set on one shell face during the season if that shell face were cleaned and returned to the water once a week. In practice a new bag of clean shells was exposed each week and all the weekly counts were added to get a total for the season.

placed on representative bars throughout the setting season. Stations were located on three oyster bars: Brown Shoal, just below the seed area; Wreck Shoal, lying in the center of the seed area among the most important bars in the river; and Deep Water Shoal, the last commercially important bar at the upper end of the seed area.

\section{RESULTS}

Weekly samples from Wreck Shoal for the summers 1947-1950, inclusive, show:

1. That setting is continuous for about three months each year, from the first of July to the first of October (Table I).

2. That the rate of setting is fairly consistent from year to year with a peak set of 18 to 39 spat per shell face per week. There have been no failures and the setting has been distributed over several weeks with the total and greatest weekly sets being of similar magnitude each year.

3. That the most intense sets occur in late August or early September and that July sets are relatively unimportant.
In Figure 2 the setting data for Wreck Shoal are expressed as weekly and monthly percentages of the total season's set. This permits comparison of seasonal distribution of set for different seasons and different bars regardless of the magnitude of the set. The four-year average was obtained for comparison with other bars and rivers. This graph shows that the July set was never more than 10 per cent of the total set during the four-year period, and that the peak of setting usually occurred near the end of August or the first of September.

In any particular year the seasonal distribution of setting on other bars in the James River corresponds closely with that of Wreck Shoal (cf. Fig. 2 and Table II). The average for these bars is very similar to the four-year average for Wreck Shoal. Thus Wreck Shoal may be considered typical for the James River as far as the pattern of setting is concerned. Loosanoff (1932) found a similar pattern at Mile's Watchhouse in 1931.

The James is compared with other Virginia rivers in Figure 3. Yorktown Fish $\mathrm{Pier}$ and Pages Rock are in the York River, while Island Bar is in the Corrotoman River, a branch of the Rappahannock. An early set of considerable importance occurred in these rivers in addition to the late set typical of the James. In 1950, 88 per cent of the set at Island Bar occurred in July. Although weekly setting records for the Rappahannock River are lacking, other records indicate that the 1948 pattern in the Corrotoman is fairly typical.

In Table III, figures on the distribution of setting show that early setting is of major importance in Maryland waters, again in contrast to the late set in the James River. St. Marys River and Holland Straits exhibit this pattern very clearly, but setting is so extremely light and spasmodic on Parker Moore Bar that the average figures may not be reliable.

It has been shown that only a small part of the strike in the James River occurs in July, while in other tributaries of Chesapeake Bay a large or major portion of setting takes place

TABLE II. Seasonal distribution of spatfall, James River

(Percentage of total set occurring monthly)

\begin{tabular}{|c|c|c|c|c|c|c|c|c|c|}
\hline \multirow{2}{*}{ Month } & \multirow{2}{*}{$\begin{array}{c}\begin{array}{c}\text { Nanse- } \\
\text { mond } \\
\text { Ridge }\end{array} \\
1947\end{array}$} & \multicolumn{2}{|c|}{ Brown Shoal } & \multirow{2}{*}{$\begin{array}{c}\begin{array}{c}\text { Mile's } \\
\text { Watch- } \\
\text { house }\end{array} \\
1931\end{array}$} & \multicolumn{3}{|c|}{ Deep Water Shoal } & \multirow{2}{*}{ Average } & \multirow{2}{*}{$\begin{array}{c}\text { Wreck } \\
\text { Shoal } \\
\text { Four Year } \\
\text { Average }\end{array}$} \\
\hline & & 1949 & 1950 & & 1947 & 1949 & 1950 & & \\
\hline $\begin{array}{l}\text { June } \\
\text { July } \\
\text { August } \\
\text { September } \\
\text { October }\end{array}$ & $\begin{array}{r}0.0 \\
3.8 \\
64.5 \\
31.7 \\
0.0\end{array}$ & $\begin{array}{r}0.0 \\
9.9 \\
71.5 \\
18.6 \\
0.0\end{array}$ & $\begin{array}{r}0.0 \\
4.9 \\
18.3 \\
76.2 \\
0.6\end{array}$ & $\begin{array}{r}0.6 \\
10.6 \\
21.4 \\
65.5 \\
1.9\end{array}$ & $\begin{array}{r}0.0 \\
4.6 \\
58.7 \\
36.7 \\
0.0\end{array}$ & $\begin{array}{r}0.0 \\
2.1 \\
79.8 \\
18.1 \\
0.0\end{array}$ & $\begin{array}{r}0.0 \\
1.8 \\
38.9 \\
59.2 \\
0.0\end{array}$ & $\begin{array}{r}0.1 \\
5.4 \\
50.4 \\
43.7 \\
0.4\end{array}$ & $\begin{array}{r}0.0 \\
7.0 \\
48.9 \\
43.7 \\
0.4\end{array}$ \\
\hline
\end{tabular}

${ }^{3}$ Data from Loosanoff 1932. 
during this month; and, late sets may be expected in many tributaries of Chesapeake Bay, but they are of major importance in the James River. Thus, the setting pattern of the James River differs from that of other areas in Chesapeake Bay and on the Atlantic Coast of North America (Beaven 1950; Hopkins 1931; Loosanoff and Nomejko 1951).

\section{Discussion}

The question may be asked, "What is the mechanism or combination of factors that causes late setting in the James River?" Numerous combinations of chemico-physical and biological factors may be responsible for variations in setting (Loosanoff 1949). The discussion that follows will be limited to certain biological

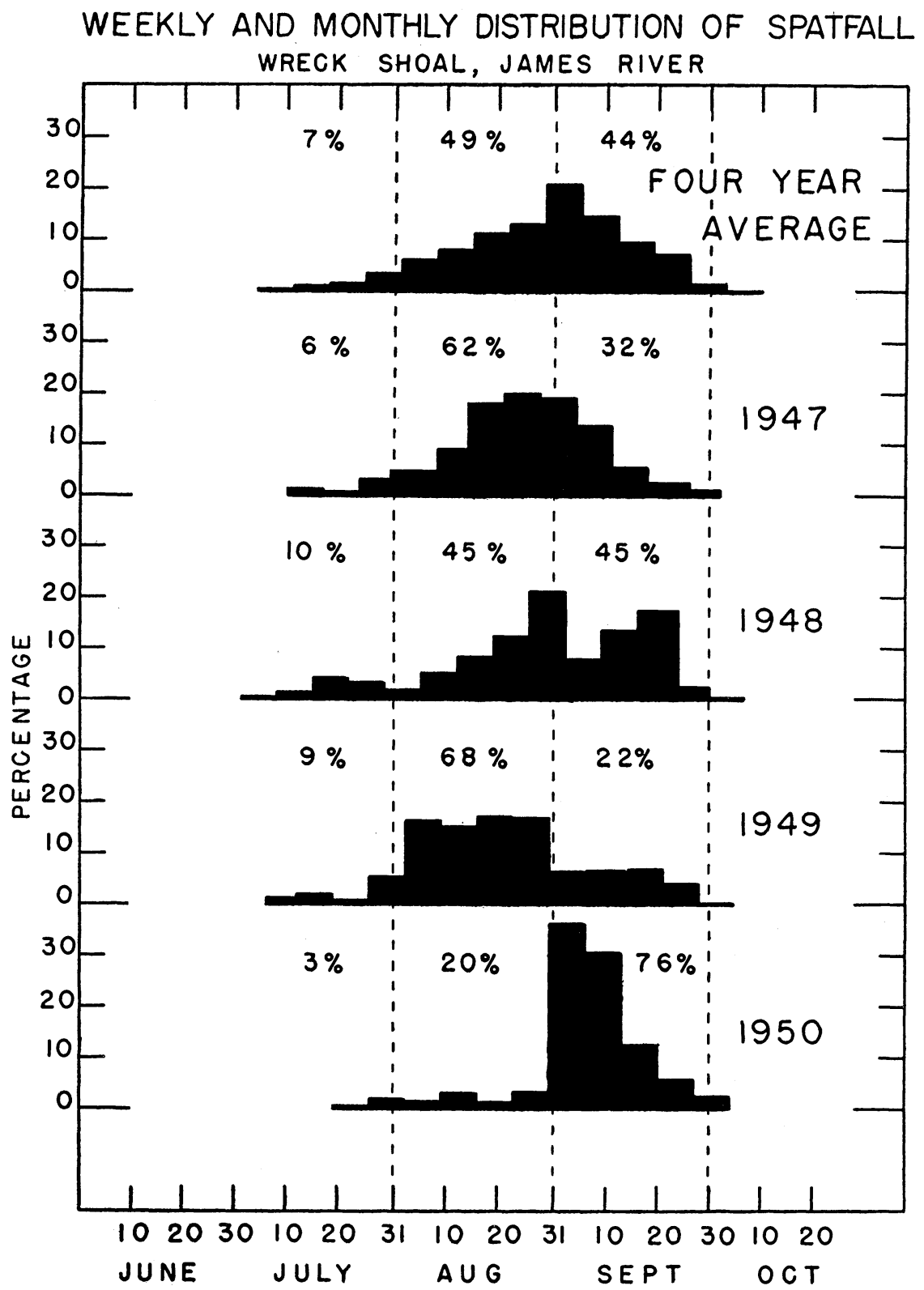

FIG. 2. Weekly and monthly distribution of spatfall, Wreck Shoal, James River. 


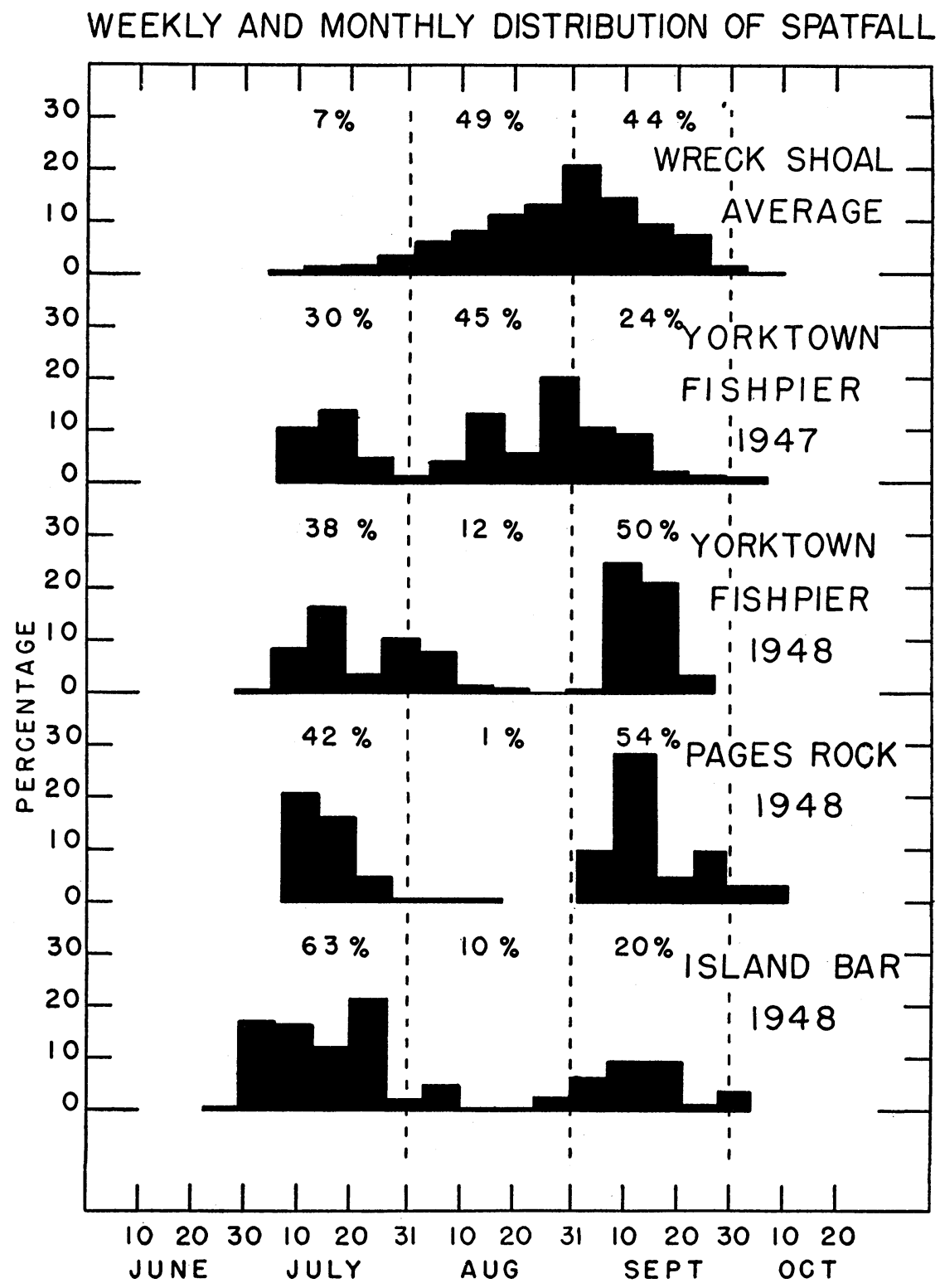

FIG. 3. Weekly and monthly distribution of spatfall at several Virginia localities.

characteristics wherein the James River seems to differ from other oyster-growing areas in Chesapeake Bay.

\section{Small size of brood oysters}

The use of the James River as a seed area and the slow growth of oysters there preclude the development of any extensive stock of large brood oysters. No important deep water beds which are out of reach of tongers have been lo- cated, so nearly all beds are subject to tonging each year. The remaining oysters are predominantly two-year old, one-year old, or currentyear spat. Since growth is very slow in the seed area, these oysters are all small. Two-year old oysters are one to two inches in length depending upon the location. While these may make up a considerable part of the total volume of oysters, the yearlings and current-year spat are far more numerous. 
TABLE III. Seasonal distribution of spatfall in Maryland waters 4

(Percentage of total set occurring monthly)

\begin{tabular}{l|c|c|c}
\hline \hline Month & $\begin{array}{c}\text { St. Marys } \\
\text { River } \\
\text { Seminary } \\
\text { Bar }\end{array}$ & $\begin{array}{c}\text { Holland } \\
\text { Straits } \\
\text { Cinder } \\
\text { Hill Bar }\end{array}$ & $\begin{array}{c}\text { Chesapeake } \\
\text { Bay } \\
\text { Marker } \\
\text { Moore Bar }\end{array}$ \\
\cline { 2 - 4 } & $\begin{array}{c}1945-1950 \\
\text { average }\end{array}$ & $\begin{array}{c}1949-1950 \\
\text { average }\end{array}$ & $\begin{array}{c}1944-1950 \\
\text { average }\end{array}$ \\
\hline June & 17.9 & 7.5 & 13.2 \\
July & 77.3 & 66.9 & 28.7 \\
August & 4.8 & 23.2 & 25.2 \\
September & 0.0 & 2.2 & 25.2 \\
October & 0.0 & 0.2 & 7.8 \\
\hline
\end{tabular}

${ }^{4} \mathrm{Mr}$. G. Francis Beaven of Chesapeake Biological Laboratory has kindly furnished the data in this table.

It is possible that oysters in the lower James and Hampton Roads furnish spawn which is carried into the seed area by tidal currents; but if we assume that setting results from spawn produced within the seed area, then the brood stock consists of large numbers of small oysters each of which produces a very limited amount of spawn. Thus small size and large numbers of oysters, and their associated spawning characteristics may constitute a significant difference in the oyster ecology of the James River as compared with other areas in Chesapeake Bay, with the possible exception of St. Marys River.

\section{Scarcity of plankton}

The paucity of net plankton in the James is another feature of interest. While detailed counts are not available, observations on three years plankton samples (No. 20 net), suggest that fewer species and smaller numbers of individuals occur in the James than in other rivers in Tidewater Virginia. A scarcity of net plankton does not necessarily imply a scarcity of nannoplankton or of oyster food. Furthermore, there is no evidence that the ultraplankton believed necessary for larval survival is lacking in the James. Conflicting views on the sizes and kinds of organisms utilized by oysters as food are given in the current literature (Korringa 1949). A paucity of net plankton could result from feeding activities of some population such as oysters at a lower level of the food chain.

The belief that plankton is scarce is supported by the observation that oysters are usually in poor condition in the James. Since these oysters fail to accumulate much glycogen in the fall, it is reasonable to assume that their spawning might be delayed by the continued feeding in spring and summer necessary to acquire the essential food reserves. Furthermore, the development of oysters to maturity or first spawning, assuming that size is more important than age, may be delayed by poor food conditions. It is possible that food scarcity causes a stock of oysters to spawn late through delayed maturity and poor condition.

\section{Sex ratio and protandry}

Coe (1938) reports among first spawners in New England as few as eight females per hundred males when nutritive conditions are not favorable. In Delaware Bay and at Beaufort, N. C., the female ratio averaged over forty per hundred but no collections from Chesapeake Bay are mentioned. The James River brood stock undoubtedly includes a high proportion of first spawners each year and it is quite apparent they are not living under favorable growing conditions. Coe (1938) and Needler (1932) also show that as a result of sex reversal the female ratio becomes higher as the population grows older and that eventually females may exceed males. Further study is needed to determine the roles of protandry and sex reversal in the failure of early sets and the success of late sets.

The James River appears to be exceptionally consistent from year to year in the amount and seasonal distribution of oyster sets. This may indicate that fewer factors regulate or limit the sets in the James than elsewhere but this very consistency may increase the difficulty of defining and delimiting those factors.

\section{SumMARY}

1. A study of seasonal patterns of oyster setting in the James River, Virginia, shows that setting is usually continuous for about 90 days, from the first of July to the first of October.

2. Setting is consistent from year to year, no failures having occurred during this study.

3. Setting is typically late in the James River with over 90 per cent occurring after the first of August in contrast to other areas of Chesapeake Bay which often get a major part of their spatfall in July.

4. The peak of setting occurs around the first of September.

5. In any particular year the rates of setting may vary from bar to bar but the percentage distribution of setting over the season is similar for all bars.

6. The small size of brood oysters, the scarcity of net plankton, and sex ratio and protandry are suggested as possible contributing factors to the late set in the James River.

\section{Literature Cited}

Beaven, G. Francis. 1950. Recent observations on the season and pattern of oyster setting in the middle Chesapeake Area. Convention Addresses Nat. Shellfisheries Assoc., 1950. [Processed.] 
Coe, W. R. 1938. Primary sexual phases in the oviparous oyster (Ostrea virginica). Biol. Bull., 74 (1) : 64-75.

Hopkins, A. E. 1931. Factors influencing the spawning and setting of oysters in Galveston Bay, Tex. Bull. U. S. Bur. of Fish., 47 (3) : 57-83.

Korringa, P. 1949. More light upon the problem of the oyster's nutrition? Bijdragen tot de Dierkunde, 28: 237-248.

Loosanoff, Victor L. 1932. Observations on propagation of oysters in James and Corrotoman Rivers and the Seaside of Virginia. The Virginia Commission of Fisheries, Newport News, Va.
-1949. Variations in intensity of setting of oysters in Long Island Sound. Convention Addresses Nat. Shellfisheries Assoc., 1949. [Processed.]

Loosanoff, V. L., and C. A. Nomejko. 1951. Spawning and setting of the American oyster, $O$. Virginica, in relation to lunar phases. Ecology, 32 (1) : 113-134.

Needler, Alfreda Berkeley. 1932. Sex reversal in Ostrea virginica. Contr. Canadian Biol. and Fish., 7 : 285-294.

\section{JAY D. ANDREWS}

Virginia Fisheries Laboratory Gloucester Point, Virginia

\section{RANGE AND HABITAT OF THE CLAM POLYMESODA CAROLINIANA (BOSC) IN VIRGINIA (FAMILY CYCLADIDAE) 1}

The clam Polymesoda caroliniana (Bosc), which ranges north and eastward in brackish waters from Lavaca Bay, Texas, ${ }^{2}$ has not previously been reported north of the Neuse River, N. C. (Van der Schalie 1933). On 7 April 1947, Richard Hoffman found several shells on the beach above Swann Point on the James River, a tributary of Chesapeake Bay (Fig. 1). On 20 April 1947, J. P. E. Morrison (personal communication) and Hoffman found living specimens in the mud and detritus around the knees of cypress trees one-half mile above Swann Point. These records are included in this paper through the courtesy of Dr. Morrison of the U. S. National Museum.

In the spring of 1949 , the authors made several field trips to determine the distribution and habitat of the species in Tidewater Virginia. Figure 1 shows the areas visited and the places where Polymesoda was found. On the north bank of the James, clams have been found from slightly above Jamestown Island to the lower end of Mulberry Island, a distance of 17 nautical miles by river. The salinity range in this area varies from nearly fresh water at Jamestown to about 15 parts per thousand at river stations opposite the tip of Mulberry Island. Table I gives the number, average length, and range in length of clams collected at each station. All clams in each collection were measured. These collections are deposited at the U. S. National Museum.

1 Contributions from the Virginia Fisheries Laboratory, No. 35.

${ }^{2}$ Dr. J. P. E. Morrison states that the specimens in the United States National Museum from Vera Cruz and Tampico, Mexico, belong to the closely related species $P$. triangula (Von dem Busch) (personal communication).
Polymesoda has not been found in the York River but several potential habitats remain to be examined.

\section{Description of Habitats}

Polymesoda is apparently restricted to intertidal habitats in the James River. Most clams have been found in a strip between mean low tide and one foot above this level. A careful search has failed to reveal the presence of this species either below the low water line or on oyster bars in the vicinity of known habitats.

These brackish-water clams have been found in three apparently diverse habitats :

1. Open river shores with eroding, sedgematted banks. Polymesoda were found in small protected crevices and often in the bottom of small depressions partially filled with finely divided plant debris and black mud. The clams were in depressions at a level six inches below the bases of living plants (Panicum and Juncus) but usually imbedded in a substratum well matted by the roots of dead plants. Stations (see Fig. 1): Mouth of Back River at Jamestown (4); Treasure Island (5); Mouth of Skiffes Creek (7); Lower Mulberry Island (10).

2. Under thick algal carpets on muddy banks of tidal creeks. Clams were found under small bulges in a thick cohesive carpet of algae covering muddy flats. This was a most remarkable habitat, for the algal mat was onequarter to one-fifth of an inch thick and probably had resulted from several seasons' growth. This implies that the larvae or young clams penetrated the mat and flourished under it, for clams of greatly varying sizes were found here. Small clams were abundant only in this habitat. The soil under the algal blanket was a fine black 